OPEN ACCESS

Edited by:

Shiying $\mathrm{He}$

Jiangsu Academy of Agricultural Sciences (JAAS), China

Reviewed by: Yuan Ge,

Research Center for Eco-Environmental Sciences (CAS), China

Tongxu Liu,

Guangdong Institute of Eco-Environmental and Soil Sciences

(CAS), China

*Correspondence: Yongjie Yu yjyu@nuist.edu.cn

Specialty section:

This article was submitted to Microbiotechnology,

a section of the journal

Frontiers in Microbiology

Received: 29 September 2021 Accepted: 23 November 2021 Published: 22 December 2021

Citation:

Zhang $X$, Dang D, Zheng L, Wu L, Wu Y, Li H and Yu Y (2021) Effect of Ag Nanoparticles on Denitrification and Microbial Community in a Paddy

Soil. Front. Microbiol. 12:785439. doi: 10.3389/fmicb.2021.785439

\section{Effect of Ag Nanoparticles on Denitrification and Microbial Community in a Paddy Soil}

\author{
Xiao Zhang ${ }^{1}$, Di Dang ${ }^{1}$, Lingsi Zheng ${ }^{1}$, Lingyu $W u^{1}$, Yu Wu ${ }^{1}$, Haoruo $\mathrm{Li}^{1}$ and Yongjie $\mathrm{Yu}^{1,2 \star}$ \\ ${ }^{1}$ Key Laboratory of Agrometeorology of Jiangsu Province, Nanjing University of Information Science and Technology, \\ Nanjing, China, ${ }^{2}$ Key Laboratory of Karst Dynamics, MNR and Guangxi, Institute of Karst Geology, Chinese Academy of \\ Geological Sciences, Guilin, China
}

The extensive application of Ag nanoparticles (AgNPs) in industry, agriculture, and food processing areas increases the possibility of its release and accumulation to agroecosystem, but the effects of AgNPs to denitrification and the microbial community in paddy ecosystems are still poorly studied. In this study, microcosmic simulation experiments were established to investigate the response of soil denitrification to different levels of AgNPs (i.e., 0.1, 1, 10, and $50 \mathrm{mg} / \mathrm{kg}$ ) in a paddy soil. Real-time quantitative PCR and high-throughput sequencing were conducted to reveal the microbial mechanism of the nanometer effect. The results showed that, though 0.1-10 mg/kg AgNPs had no significant effects on denitrification rate and $\mathrm{N}_{2} \mathrm{O}$ emission rate compared to $\mathrm{CK}$ and bulk Ag treatments, $50 \mathrm{mg} / \mathrm{kg}$ AgNPs significantly stimulated more than $60 \%$ increase of denitrification rate and $\mathrm{N}_{2} \mathrm{O}$ emission rate on the 3rd day $(P<0.05)$. Real-time quantitative PCR revealed that $50 \mathrm{mg} / \mathrm{kg}$ AgNPs significantly decreased the abundance of $16 S$ bacterial rRNA gene, nirS/nirK, cnorB, and nosZ genes, but it did not change the narG gene abundance. The correlation analysis further revealed that the cumulative $\mathrm{N}_{2} \mathrm{O}$ emission was positively correlated with the ratio of all the five tested denitrifying genes to bacterial 16S rRNA gene ( $P<0.05)$, indicating that the tolerance of narG gene to AgNPs was the key factor of the increase in denitrification in the studied soil. High-throughput sequencing showed that only the $50-\mathrm{mg} / \mathrm{kg}$-AgNP treatment significantly changed the microbial community composition compared to bulk $\mathrm{Ag}$ and $\mathrm{CK}$ treatments. The response of microbial phylotypes to AgNPs suggested that the most critical bacteria which drove the stimulation of $50 \mathrm{mg} / \mathrm{kg} \mathrm{AgNPs}$ on $\mathrm{N}_{2} \mathrm{O}$ emission were Firmicutes and $\beta$-proteobacteria, such as Clotridiales, Burkholderiales, and Anaerolineales. This study revealed the effects of AgNPs to denitrification in a paddy ecosystem and could provide a scientific basis for understanding of the environmental and toxicological effects of Ag nanomaterials.

Keywords: Ag nanoparticles, paddy soil, nitrous oxide, denitrifying genes, high-throughput sequencing 


\section{INTRODUCTION}

Nanomaterials were widely applied in a multitude of industries due to their advantages in special physiochemical properties, quantum size effect, and specific surface activity (Maynard et al., 2006; Gan and Li, 2012; Goldberg, 2019; He et al., 2019; Nasrollahzadeh et al., 2021). The global consumption of nanoparticles is predicted to be $\sim 900$ tons per year by 2030 (Olteanu et al., 2017; Yaqoob et al., 2020). Among nanoparticles like $\mathrm{Au}, \mathrm{ZnO}, \mathrm{CuO}, \mathrm{TiO}_{2}$, and $\mathrm{Fe}_{2} \mathrm{O}_{3}$, silver nanoparticle (AgNPs) is a typically widely used nanomaterial due to its significant advantages in electrical conductivity, antibiosis, and localized surface plasmon resonance properties (Salleh et al., 2020). These vital properties of AgNP make it not only prominent in the industries of photonics, microelectronics, and catalysis but also popular in healthcare, environmental preservation, and bactericide in agriculture (Hamad et al., 2020). With the application of AgNPs spanning across diverse fields, it inevitably increases the possibility of its release and accumulation in natural environments (Whitley et al., 2013; Prosposito et al., 2020). It has been reported to be found in various ecosystems, such as oceans, freshwater, wetland, and soils (Lead and Wilkinson, 2006; Wilson et al., 2008). According to the modeling results, the emission of nanomaterials in a soil environment is much more abundant than that in aquatic and atmospheric environments (Gottschalk et al., 2009; Sun et al., 2014). Although the application of AgNPs in agriculture is a prospective area (Pradas Del Real et al., 2016), the influence of AgNPs on soil ecosystem is still not fully understood.

Paddy soils support the staple diet for nearly $50 \%$ of the global population (according to FAOSTAT in 2019). The negative effects of engineered nanomaterials on the paddy ecosystem gained great concerns in recent years. Long-term anaerobic and lowoxygen conditions make soil denitrification the main nitrogen cycling process (Cai et al., 1997). Since the oxidation of AgNPs to silver ions inevitably changes the electron transport chain processes, soil denitrification, a series of biochemical oxidationreduction reactions, might be influenced by the released AgNPs in a paddy ecosystem. Furthermore, the potentially influenced soil $\mathrm{N}_{2} \mathrm{O}$ emission in denitrification is also an important content in the risk assessment of the released AgNPs. It has been reported that $1 \mathrm{mg} / \mathrm{L}$ AgNPs inhibited the nitrogen cycling processes in a sludge treatment system (Liang et al., 2010). Zheng et al. (2017) demonstrated that $2 \mathrm{mg} / \mathrm{L}$ AgNPs significantly changed the denitrification processes and stimulated $\mathrm{N}_{2} \mathrm{O}$ emission in aquatic ecosystems. So far, the environmental risk assessment of AgNPs is still at the primary stage, and lots of investigations concentrate on the aquatic ecosystem. Thus, the knowledge gap concerning the influence of AgNPs on denitrification in paddy ecosystems still remains.

Soil microorganism, which drives the conversion of organic carbon and nutrient cycling, is considered as one of the most important sensitive indicators in terrestrial ecosystems. It has been well-known that a microbial community could dynamically regulate them to the change of environmental factors (Delgado-Baquerizo et al., 2016; Zheng et al., 2017), so it may be perceptive to the exposure of AgNPs. It has been demonstrated that microbial community and diversity can be significantly influenced by AgNPs (Cao et al., 2017; Samarajeewa et al., 2017; Zhang et al., 2020). Kumar et al. (2011) demonstrated that the amendment of $50 \mathrm{mg} \mathrm{kg}^{-1}$ AgNPs altered the soil bacterial community structures in arctic soil. Wang et al. (2017) also reported that the AgNP concentration of more than $20 \mathrm{mg} / \mathrm{kg}$ seriously inhibited the growth of soil microbes in suburban vegetable soils. Yang et al. (2013) demonstrated that AgNPs significantly inhibit the abundance and activity of Nitrosomonas europaea in sewage treatment systems. It can be inferred that AgNPs could show exhibited toxicity to soil-denitrifying communities when it is exposed to a paddy ecosystem. Although there is rich literature examining the responses of microbial community and function to AgNPs (Kent et al., 2014; Guo et al., 2019; Huang et al., 2019a), few studies investigate how AgNPs affect denitrifying communities in paddy soil ecosystems. More specifically, the underlying mechanistic details of the denitrifying community and the phylogenetic structure in response to different AgNP concentrations in paddy soils are seldom available.

Here we applied different concentrations of AgNPs to paddy soil at the microcosmic scale under laboratory conditions in order to simulate the scenarios of nanomaterial exposed to a paddy ecosystem. A combination of real-time quantitative PCR and high-throughput sequencing technologies was conducted to reveal the microbial mechanism underneath the response of denitrification to AgNPs. This study aims to enhance our understanding of the impacts that AgNPs bring to paddy soil and provide a theoretical and scientific basis for better evaluating the ecological effects of nanomaterials in agriculture.

\section{MATERIALS AND METHODS}

\section{Soils and Nanoparticles}

The tested paddy soil samples were from Yingtan, Jiangxi Province $\left(116^{\circ} 55^{\prime} 30^{\prime \prime}\right.$ E, $\left.28^{\circ} 15^{\prime} 20^{\prime \prime} \mathrm{N}\right)$. Surface $(0-15 \mathrm{~cm})$ soil was obtained after rice paddy harvest. Fresh soil was sieved through a $2-\mathrm{mm}$ mesh, with visible roots, stones, and macro-fauna removed. One subsample was air-dried for chemical analyses. One fresh subsample was stored at $4^{\circ} \mathrm{C}$ before analysis, whereas the residual subsample was immediately stored at $-80^{\circ} \mathrm{C}$ for molecular analysis. The $\mathrm{pH}$ of the tested soil was 5.01 , soil organic carbon was $14.58 \mathrm{~g} / \mathrm{kg}$, total nitrogen was $1.09 \mathrm{~g} / \mathrm{kg}, \mathrm{NO}_{3}^{-}-\mathrm{N}$ was $1.2 \mathrm{mg} / \mathrm{kg}$, and $\mathrm{NH}_{4}^{+}-\mathrm{N}$ was $4.4 \mathrm{mg} / \mathrm{kg}$.

AgNP was synthesized with a chemical reduction method described according to Feng et al. (2013). In detail, firstly, a precursor of $0.01 \mathrm{M} \mathrm{AgNO}_{3}$ solution and 1\% PVP (molecular weight $=40,000)$ were mixed at a molar ratio of 1:1.45 to get an optimum stabilizing effect of PVP with a minimum particle size. Then, $\mathrm{AgNO}_{3}$ solution was added drop by drop to a stirred and preheated $\left(60^{\circ} \mathrm{C}\right)$ solution with the components of $0.01 \mathrm{M}$ $\mathrm{NaOH}$ and $0.02 \mathrm{M}$ glucose (about 30 drops per minute). The $\mathrm{pH}$ range throughout the reaction was kept in between 8.5 and 9.0. Stirring of the solution lasted until $10 \mathrm{~min}$ after all the $\mathrm{AgNO}_{3}$ solution was added. Then, the obtained brownish-silver colloid was centrifuged and washed with distilled water several times until no nitrate could be traced. The precipitated AgNPs 


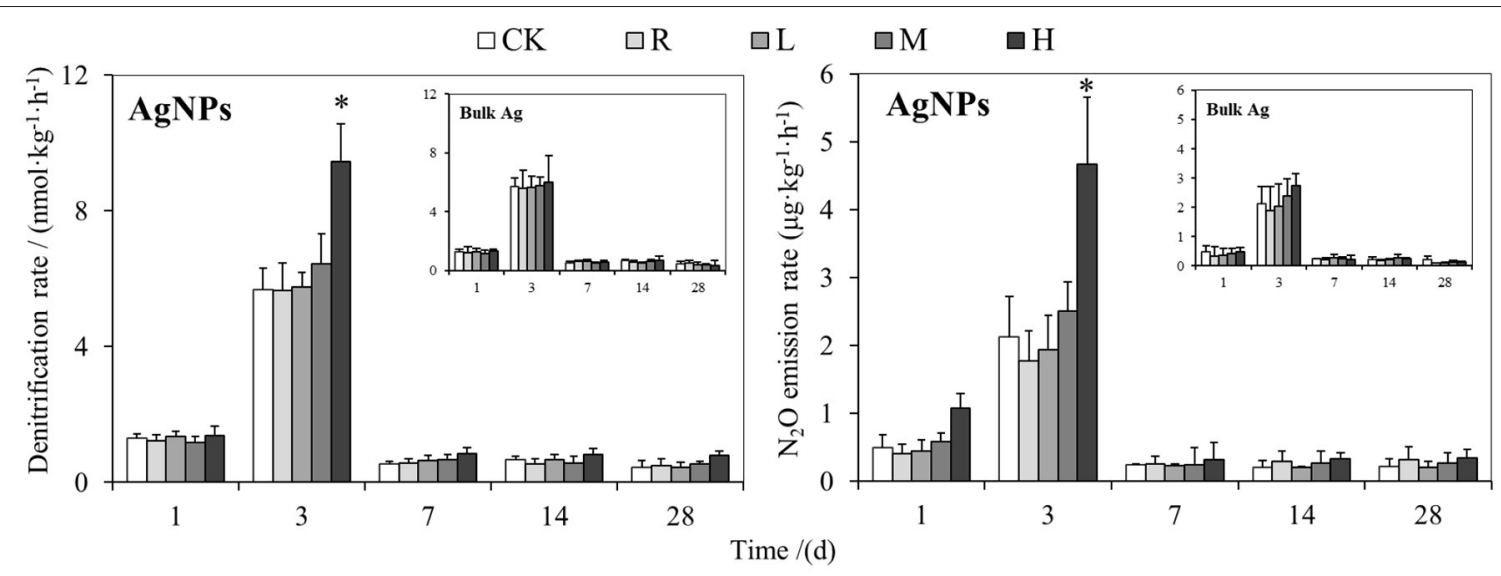

FIGURE 1 | The effects of AgNPs on denitrification and $\mathrm{N}_{2} \mathrm{O}$ emission rate in a paddy soil. R, L, M, and $\mathrm{H}$ represent $0.1,1,10$, and $50 \mathrm{mg} / \mathrm{kg}$, respectively. CK indicates the treatments without $\mathrm{Ag}$ particle amendment. Asterisks above the bars represent a significant difference at the 0.05 level.

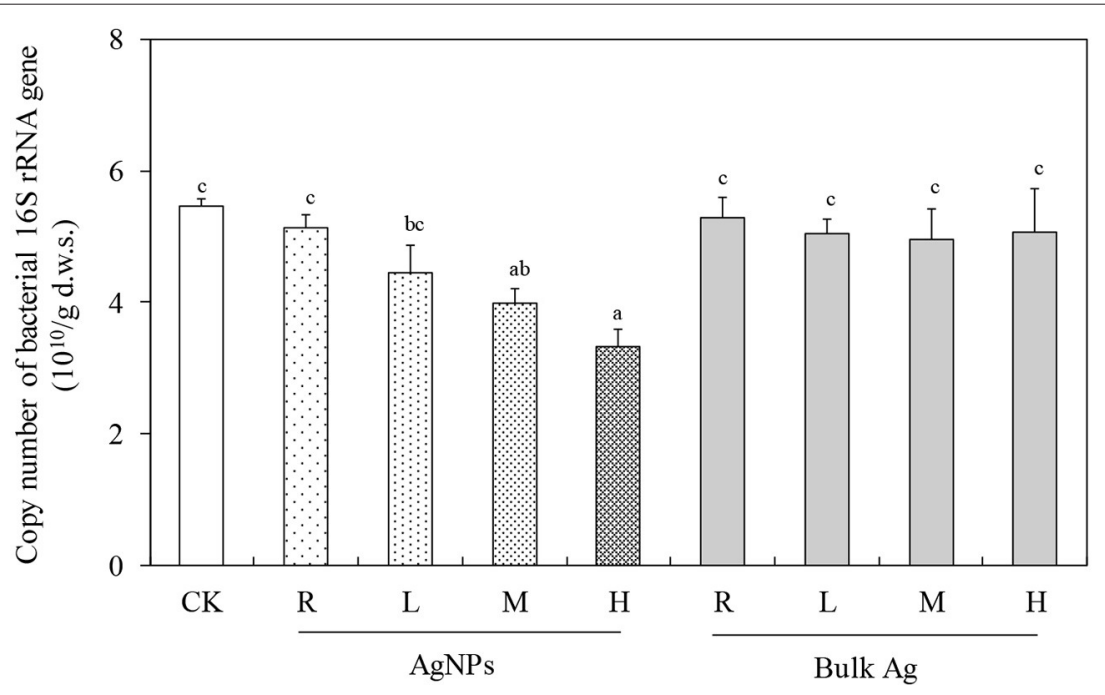

FIGURE 2 | The effects of AgNPs on bacterial 16S rRNA gene abundance in a paddy soil. R, L, M, and H represent 0.1, 1, 10, and 50 mg/kg, respectively. CK indicates the treatments without Ag particle amendment. Lowercase letters above the bars represent a significant difference at the 0.05 level.

were separated by centrifugation at $4,000 \times g$ for $10 \mathrm{~min}$ and subsequently allowed to air-dry in a desiccator. The dry silver particles were re-dispersed and washed with deionized water and dispersed by ultrasonic oscillation to obtain a stable and uniform aqueous solution. The average size of the synthesized AgNPs in this study was $20.5 \pm 3.5 \mathrm{~nm}$. The zeta potential $(\zeta)$ of AgNPs was $-22.9 \pm 1.1 \mathrm{mV}$. Bulk Ag powder was purchased from Sinopharm Chemical Reagent Co., Ltd., China. The particle size of the bulk Ag powder was $\sim 5.0 \mu \mathrm{m}$.

\section{Experimental Design}

For each soil sample, a series of 250-ml Erlenmeyer flask was prepared with $30 \mathrm{~g}$ soil (oven-dry basis) and then divided into three groups, i.e., AgNPs, bulk Ag, and control (without Ag particle amendment). Four levels of AgNPs or bulk Ag were applied to each soil sample with the concentrations of $0.1(\mathrm{R})$,
1 (L), $10(\mathrm{M})$, and $50 \mathrm{mg} \mathrm{kg}^{-1}(\mathrm{H})$, which were commonly used in studies of the effects of AgNPs on the ecosystem (Kumar et al., 2011; Zheng et al., 2017). Both AgNPs and bulk Ag were dispersed with 20-min sonication at $600 \mathrm{~W}$; then, the suspensions were added drop by drop to the tested soils to homogenize the Ag particles and soil samples. A certain amount of sterile water was added to each flask to make the ratio of water to soil at 1:1. Silicone sealant was used around the plug to ensure anaerobic conditions. The flasks were connected to a multiport vacuum manifold, which allowed 20 flasks to be simultaneously vacuumed and flushed with oxygen-free $\mathrm{N}_{2}$ gas. The procedure was repeated three times (each for $10 \mathrm{~min}$ ) to create an anaerobic headspace. Following equilibration at atmospheric pressure, the flasks were incubated at $25^{\circ} \mathrm{C}$ in the dark. A certain amount of sterile water was injected in order to ensure moisture during the whole incubation process. Sampling was performed on the 

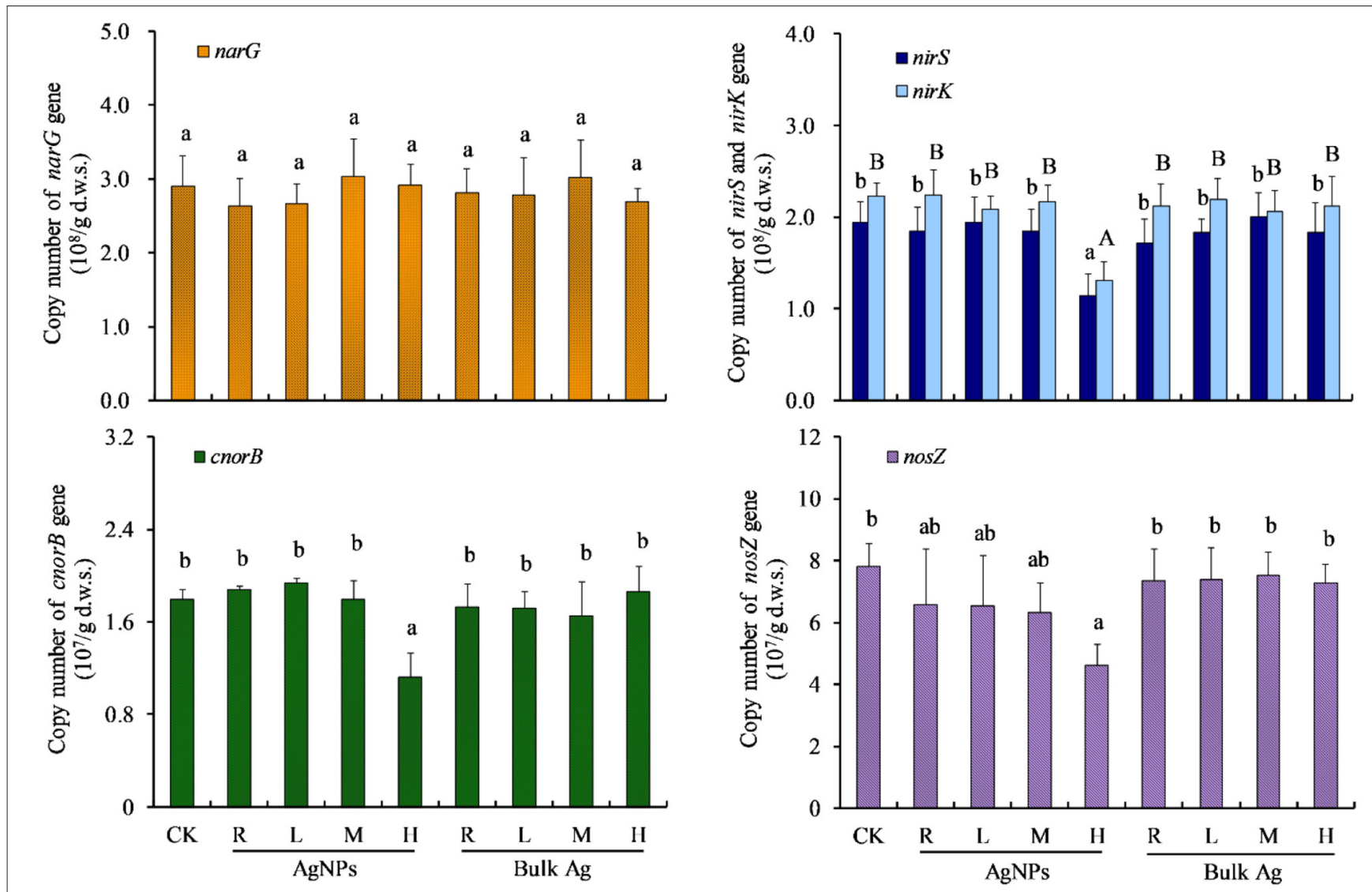

FIGURE 3 | The effects of AgNPs on denitrification functional gene abundance in a paddy soil. R, L, M, and H represent $0.1,1,10$, and 50 mg/kg, respectively. CK indicates the treatments without Ag particle amendment. Different letters above the bars represent a significant difference at the 0.05 level.

1st, 3rd, 7th, 14th, and 28th day. The denitrification rate was measured by acetylene inhibition method (Yu et al., 2013). The $\mathrm{N}_{2} \mathrm{O}$ concentration was determined using a 2-mm ID stainless steel column, $3 \mathrm{~m}$ in length and packed with Porapak Q (80/100 mesh), and an Agilent 7890 gas chromatograph fitted with an electron capture detector set at $300^{\circ} \mathrm{C}$.

\section{Molecular Methods}

Soil total DNA was extracted from $0.5 \mathrm{~g}$ fresh soil using the FastDNA ${ }^{\circledR}$ SPIN Kit for soil (MP Biomedicals, Santa Ana, CA, USA) according to the instructions of the manufacturer. The quality and quantity of DNA were checked using a NanoDrop spectrophotometer (NanoDrop Technologies Inc., Wilmington, DE, USA). The soil DNA was stored under $-20^{\circ} \mathrm{C}$ before using.

Quantitative real-time PCR was performed on the target denitrifying genes, i.e., narG, nirS, nirK, $\operatorname{cnorB}$, and nos $Z$ genes, and bacterial $16 \mathrm{~S}$ rRNA gene in triplicate according to Yu et al. (2013) in a CFX96 Real-Time system (Bio-Rad, CA, USA). Standard curves were created using 10-fold dilution series of linearized plasmids with target genes inserted. The PCR mixtures for each gene contained 1.0 $\mu \mathrm{l}$ DNA template, $12.5 \mu \mathrm{l}$ of SYBR ${ }^{\circledR}$ Premix Ex Taq ${ }^{\mathrm{TM}}$ (TaKaRa, Dalian, China), and $100 \mathrm{nM}$ of each primer. Thermocycling consisted of $95^{\circ} \mathrm{C}$ for $5 \mathrm{~min}$, followed by 40 cycles of $95^{\circ} \mathrm{C}$ for $10 \mathrm{~s}$ and annealing for $30 \mathrm{~s}$, and $72^{\circ} \mathrm{C}$ for $60 \mathrm{~s}$. The annealing temperature was set according to our previous study (Yu et al., 2013). The amplification efficiency was controlled in the range of $90-110 \%$; the standard curve coefficient correlations were between 0.97 and 0.99 .

High-throughput sequencing of the bacterial 16S rRNA gene was performed according to our previous study (Yu et al., 2019) on Miseq platform (Illumina Inc., CA, USA). In detail, the primer set $519 \mathrm{~F}$ and $907 \mathrm{R}$ was used to amplify $\sim 400$ bp of bacterial $16 \mathrm{~S}$ rRNA gene fragments. The oligonucleotide sequences included a 5-bp barcode fused to the forward primer as follows: barcode + forward primer. PCR was carried out in $50-\mu l$ reaction mixtures with the following components: $4 \mu \mathrm{l}$ (initial $2.5 \mathrm{mM}$ each) of deoxynucleoside triphosphates, $2 \mu \mathrm{l}$ (initial $10 \mathrm{mM}$ each) of forward and reverse primers, $2 \mathrm{U}$ of Taq DNA polymerase with $0.4 \mu \mathrm{l}$ (TaKaRa, Dalian, China), and $1 \mu \mathrm{l}$ of template containing $\sim 50 \mathrm{ng}$ of genomic community DNA as a template. Furthermore, $95^{\circ} \mathrm{C}$ for $5 \mathrm{~min}$ and 25 cycles of $95^{\circ} \mathrm{C}$ for $45 \mathrm{~s}, 56^{\circ} \mathrm{C}$ for $45 \mathrm{~s}$, and $72^{\circ} \mathrm{C}$ for $60 \mathrm{~s}$ were performed, with a final extension at $72^{\circ} \mathrm{C}$ for $7 \mathrm{~min}$. The purified barcoded PCR products from all of the samples were normalized in equimolar amounts, then prepared using TruSeq ${ }^{\mathrm{TM}}$ DNA Sample Prep LT Kit, and sequenced using MiSeq Reagent Kit v3 (600-cycles-PE) following the protocols of the manufacturer. Moreover, $10 \%$ PhiX control library was added to the tested DNA sample before sequencing. The obtained raw 

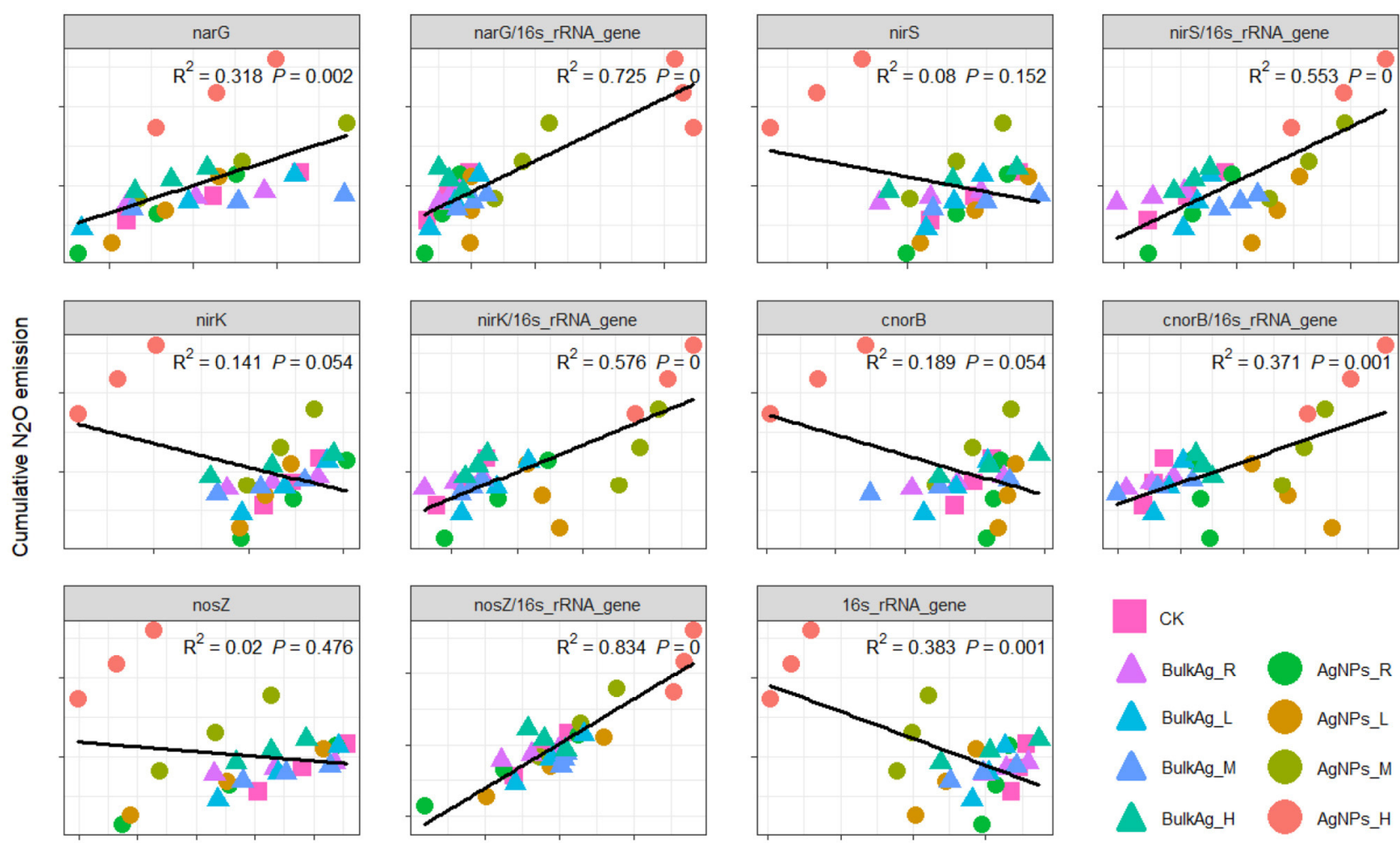

Genes

FIGURE 4 | Correlation between cumulative $\mathrm{N}_{2} \mathrm{O}$ emission and denitrifying genes under different application levels of AgNPs in a paddy soil. R, L, M, and $\mathrm{H}$ represent $0.1,1,10$, and $50 \mathrm{mg} / \mathrm{kg}$, respectively. CK indicates the treatments without Ag particle amendment.

sequencing data were uploaded to NCBI Sequence Read Archive database with the accession number of PRJNA768985.

\section{Statistical Analysis}

The analysis of bacterial sequencing data was performed with Quantitative Insights Into Microbial Ecology (QIIME) 1.9.1 pipeline (Caporaso et al., 2010). Briefly, the sequences were binned into OTUs using $97 \%$ identity threshold, and the most abundant sequence from each OTU was selected as a representative sequence for that OTU. Taxonomy was assigned to bacterial OTUs against a subset of the Greengene 13.8 database. Usearch was used to remove chimera and aligned OTU representative sequences (Edgar, 2013). The weighted pairwise UniFrac distances (Ley et al., 2005) were calculated for community comparisons using beta_diversity_through_plots.py in QIIME. The one-way analysis of variance (ANOVA), permutational multivariate analysis of variance (PERMANOVA), and heat map analysis were calculated with vegan, ggplot2, and reshape 2 packages in $\mathrm{R}$ software (Fine and Kembel, 2011). A correlation analysis was quantified using analysis of variance. The responses of bacterial species to different treatments were visualized with STAMP (Parks et al., 2014). Differences at $P<$ 0.05 were considered statistically significant.

\section{RESULTS}

\section{Effect of AgNPs on Soil Denitrification and $\mathrm{N}_{2} \mathrm{O}$ Emission Rate}

The responses of soil denitrification and $\mathrm{N}_{2} \mathrm{O}$ emission rate to different concentrations of AgNPs are shown in Figure 1. The peak value of soil denitrification rate was $5.68 \pm 0.63 \mathrm{nmol}$ $\mathrm{kg}^{-1} \mathrm{~h}^{-1}$ at day 3 in the CK treatments; then, it decreased to a range between 0.44 and $0.68 \mathrm{nmol} \mathrm{kg}^{-1} \mathrm{~h}^{-1}$ in the tested paddy soil. The $\mathrm{N}_{2} \mathrm{O}$ emission rate reached a peak value of $2.13 \pm 0.60 \mu \mathrm{g} \mathrm{kg}^{-1} \mathrm{~h}^{-1}$ at day 3, and then it changed between 0.01 and $0.02 \mu \mathrm{g} \mathrm{kg}^{-1} \mathrm{~h}^{-1}$. The peak values of denitrification and $\mathrm{N}_{2} \mathrm{O}$ emission rate in AgNP treatment were also observed at day 3. Furthermore, $50 \mathrm{mg} / \mathrm{kg}(\mathrm{H}) \mathrm{AgNPs}$ significantly increased both the denitrification and $\mathrm{N}_{2} \mathrm{O}$ emission rate at day $3(P<0.05)$, but it did not significantly change the denitrification and $\mathrm{N}_{2} \mathrm{O}$ emission rate at all the other incubation times $(P>0.05)$. The other three concentrations, 0.1 (R), 1 (L), and $10 \mathrm{mg} / \mathrm{kg}(\mathrm{M})$, of AgNPs did not significantly influence the soil denitrification and $\mathrm{N}_{2} \mathrm{O}$ emission rate at the same incubation time $(P>0.05)$. No significant difference of denitrification and $\mathrm{N}_{2} \mathrm{O}$ emission rate was observed between bulk $\mathrm{Ag}$ treatment and $\mathrm{CK}$ at the same incubation time $(P$ $>0.05)$. 


\section{Effect of AgNPs on Bacterial and Denitrifying Genes}

The response of bacterial 16S rRNA gene abundance to different concentrations of AgNPs is shown in Figure 2. The copy number

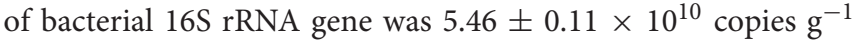
d.w.s. in the CK treatment. A concentration effect was observed in different AgNP treatments, that is, the bacterial abundance decreased with the increase in concentration of AgNPs in the tested paddy soil. In detail, 0.1 (R) and $1 \mathrm{mg} / \mathrm{kg}$ (L) AgNPs showed a decreasing trend compared to $\mathrm{CK}$, though there was no significant difference between them $(P>0.05)$. Both $10(\mathrm{M})$ and $50 \mathrm{mg} / \mathrm{kg}(\mathrm{H})$ AgNPs significantly decreased the soil bacterial abundance compared to CK $(P<0.05)$. In addition, $50 \mathrm{mg} / \mathrm{kg}$ $(\mathrm{H})$ AgNPs had the lowest abundance of soil bacteria $\left(2.31 \times 10^{10}\right.$ copies $\mathrm{g}^{-1}$ d.w.s.) and decreased by about $57.7 \%$ of that of CK. No significant difference of bacterial abundance was observed between bulk Ag treatment and CK $(P>0.05)$.

The abundance of narG, nirS, nirK, cnorB, and nos $Z$ denitrifying genes in CK were $2.90 \times 10^{8}, 1.94 \times 10^{8}, 2.23 \times$ $10^{8}, 1.80 \times 10^{7}$, and $7.81 \times 10^{7}$ copies $\mathrm{g}^{-1} \mathrm{~d}$.w.s., respectively (Figure 3). Moreover, 0.1 (R), 1 (L), and $10 \mathrm{mg} / \mathrm{kg}$ (M) AgNPs did not significantly change the nirS, nirK, cnorB, and nos $Z$ genes $(P>0.05)$. Furthermore, $50 \mathrm{mg} / \mathrm{kg}$ AgNPs also showed no significant difference in narG gene abundance $(P>0.05)$, but it significantly decreased the abundance of nirS, nirK, cnor $B$, and nos $Z$ genes $(P<0.05)$. No significant difference of denitrifying gene abundance was observed between bulk Ag treatment and CK $(P>0.05)$.

To unravel the key microbial factor/s driving the denitrification process, correlation analyses were performed between cumulative $\mathrm{N}_{2} \mathrm{O}$ emission and the abundance of microbial genes in the tested paddy soil (Figure 4). The cumulative $\mathrm{N}_{2} \mathrm{O}$ emission was found to be positively significantly correlated with soil narG gene abundance $(R=0.564, P<0.05)$, but it was not significantly correlated with nirS, nirK, cnorB, and nos $Z$ genes $(P>0.05)$. A negatively significant relationship was observed between cumulative $\mathrm{N}_{2} \mathrm{O}$ emission and bacterial $16 \mathrm{~S}$ rRNA gene $(R=-0.619, P<0.05)$. Further analyses showed that soil cumulative $\mathrm{N}_{2} \mathrm{O}$ emission was positively related with the ratio of all the five denitrifying genes to bacterial $16 \mathrm{~S}$ rRNA gene copies $(P \leq 0.001)$.

\section{Effect of AgNPs on Microbial Community}

To reveal the response of microbial community to AgNPs, highthroughput sequencing was performed on Miseq platform. In total, we obtained 435,827 sequences in the tested soils and 14,647-26,129 sequences per sample. Taxonomy against gene bank showed $99.3 \%$ bacteria, 34.60\% Proteobacteria, $14.90 \%$ Acidobacteria, $11.70 \%$ Chloroflexi, $8.00 \%$ Actinobacteria, and 7.90\% Firmicutes. According to the weighted distance of UniFrac obtained by non-metric multi-dimensional scaling (NMDS), the distribution of community composition of methanogenic archaea under different treatments is shown in Figure 5. NMDS showed that the soil bacterial community composition differed with the increase of AgNP concentration (Figure 5). The PERMANOVA result found no significant difference

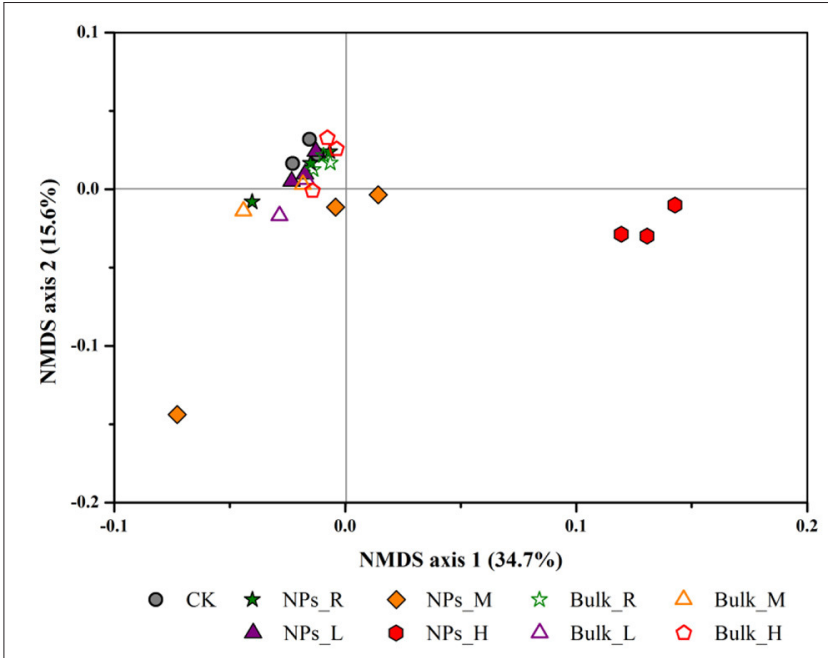

FIGURE 5 | Bacterial community compositional structure as indicated by a non-metric multi-dimensional scaling plot of the weighted pairwise UniFrac community distances under different concentrations of AgNPs in a paddy soil. $\mathrm{R}, \mathrm{L}, \mathrm{M}$, and $\mathrm{H}$ represent $0.1,1,10$, and $50 \mathrm{mg} / \mathrm{kg}$, respectively. CK indicates the treatments without Ag particle amendment.

between $\mathrm{CK}$ and $0.1(\mathrm{R}), 1$ (L), and $10 \mathrm{mg} / \mathrm{kg}(\mathrm{M})$ AgNP treatments. The bacterial community composition of $50 \mathrm{mg} / \mathrm{kg}$ (H) AgNP treatments was significantly different from all the other treatments $(P<0.01)$. The bulk Ag treatments did not significantly change the bacterial community composition compared to the CK treatments $(P>0.05)$.

To unravel the key microbial phylotype/phylotypes related to the influence of AgNPs on soil denitrification, bacteria at different taxonomy levels were statistically analyzed between different treatments in the tested paddy soil (Figure 6). At the phylum level, $50 \mathrm{mg} / \mathrm{kg}(\mathrm{H})$ AgNPs decreased Acidobacteria, Actinobacteria, Elusimicrobia, and Cyanobacteria, while it increased Firmicutes and WS5 phyla (Figure 6A). Moreover, 0.1 (R), 1 (L), and $10 \mathrm{mg} / \mathrm{kg}(\mathrm{M})$ AgNP treatments rarely changed the bacterial phyla compared to that of $\mathrm{CK}$ treatments (Figure 6A). At the class level, $50 \mathrm{mg} / \mathrm{kg}(\mathrm{H})$ AgNPs decreased Deltaproteobacteria, Gammaproteobacteria, and Ktedonobacteria, while it increased Betaproteobacteria, Clostridia, Bacterodia, and OPB41 (Figure 6B). At the order level, the response ratio analyses showed that $50 \mathrm{mg} / \mathrm{kg}(\mathrm{H})$ AgNPs significantly decreased most of the bacteria orders but increased Clotridiales, Burkholderiales, and Anaerolineales $(P$ $<0.05)$.

\section{DISCUSSION}

The highly commercialized AgNPs could be enriched, migrated, or transformed in the soil ecosystem due to its remarkable characteristics, such as specific surface activity and active physiochemical properties (Wilson et al., 2008; Sun et al., 2014). The potential influences of AgNPs on soil ecosystems are highly concerning (He et al., 2019; Lowry et al., 2019). In this study, 

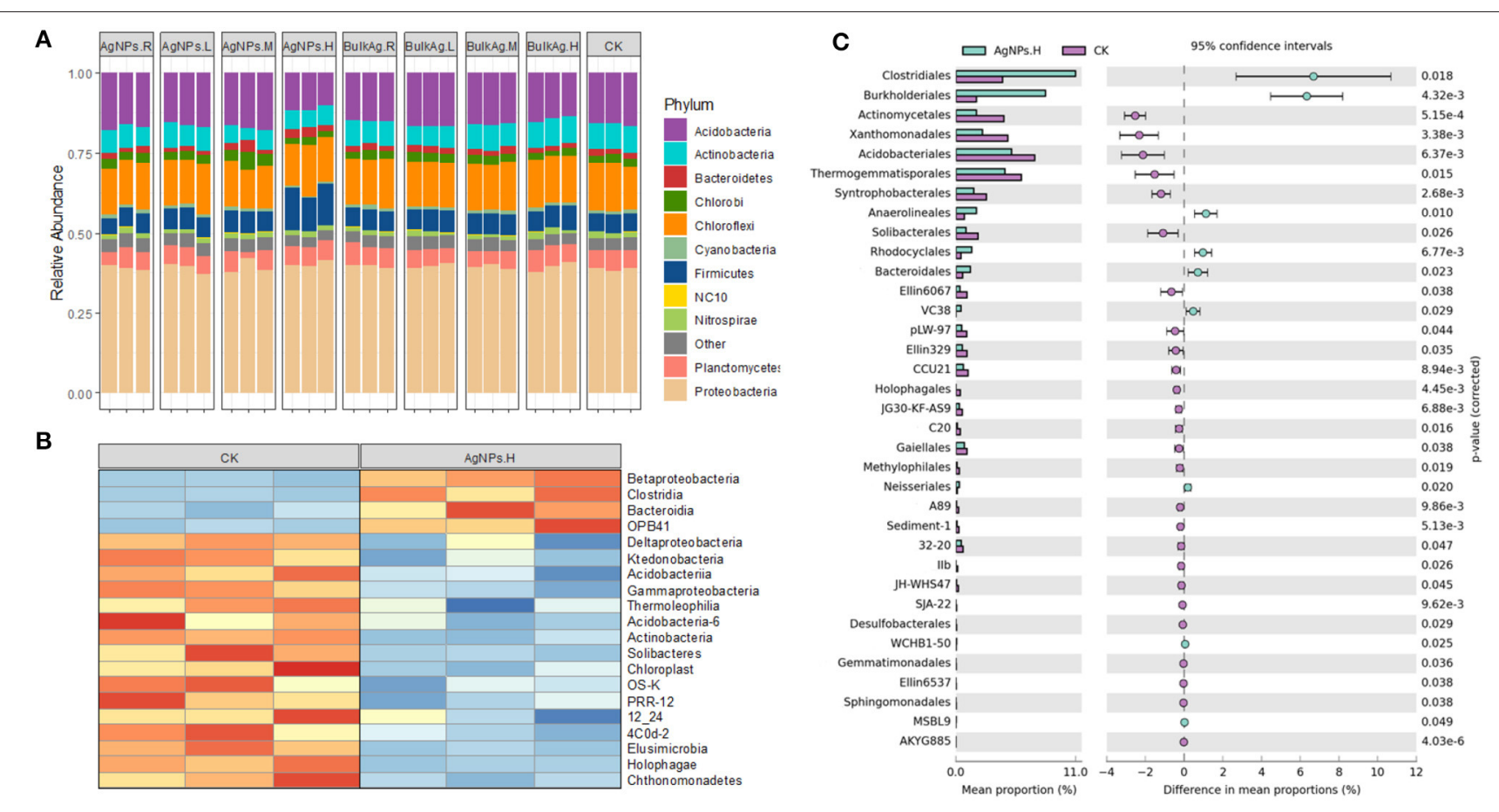

FIGURE 6 | The bacterial community variation characteristic under different concentrations of AgNPs in a paddy soil. (A) The relative abundance of soil bacteria at the phylum level. (B) The heat map of soil bacteria at the class level. (C) The response ratio of soil bacteria at the order level. R, L, M, and $\mathrm{H}$ represent $0.1,1,10$, and 50 $\mathrm{mg} / \mathrm{kg}$, respectively. CK indicates the treatments without Ag particle amendment.

a series of microcosm experiments was conducted to simulate the scenario of a paddy ecosystem exposed under different concentrations of AgNP. The responses of soil denitrification and microbial community were investigated by anaerobic incubation and molecular methods.

\section{Responses of Soil Denitrification Rate to AgNPs}

The oxidation process of AgNPs to silver ions in soils inevitably changes the electron transport chain processes in soils (Huang et al., 2019b) and subsequently influences nitrogen cycling that is substantially biochemical reduction and oxidation reactions. Previous studies found that $1 \mathrm{mg} / \mathrm{kg}$ AgNPs could inhibit the nitrification bacteria (Choi and Hu, 2008; Radniecki et al., 2011). Grün et al. (2018) demonstrated that a 1-year application of low-concentration AgNPs (0.01-1 mg/kg) could cause a negative influence on soil Azotobacter and ammonia bacteria. In this study, we found that neither denitrification nor $\mathrm{N}_{2} \mathrm{O}$ emission rate was significantly influenced by the $0.1-10 \mathrm{mg} / \mathrm{kg}$ AgNPs $(P$ $>0.05)$. This phenomenon mainly resulted from the complex environment in paddy soils, which is radically different from laboratory culture and aquatic environments. When AgNPs $(<10$ $\mathrm{mg} / \mathrm{kg}$ ) was exposed to soils, it could be captured by colloidal solids, clay minerals, iron oxides, and manganese oxides in soils (Alvarez and Cervantes, 2012; Vandevoort et al., 2014), and then the toxicity of AgNPs might be buffered. This finding is consistent with the previous study, in which $1 \mathrm{mg} / \mathrm{kg}$ AgNP did not change the denitrification in a sediment environment (Liu et al., 2018).
A high concentration up to $50 \mathrm{mg} / \mathrm{kg}$ AgNPs significantly changed both the denitrification and $\mathrm{N}_{2} \mathrm{O}$ emission rate in this study $(P<0.05)$. We found that bulk $\mathrm{Ag}$ treatments had no influences on denitrification and $\mathrm{N}_{2} \mathrm{O}$ emission rate compared to $\mathrm{CK}$ treatment, indicating that the influence of high-concentration AgNPs on soil denitrification resulted from a nanometer effect. Interestingly, the effects of $50 \mathrm{mg} / \mathrm{kg}$ AgNPs on soil denitrification did not show an inhibition effect; it was a stimulating effect. The possible reason for this phenomenon might be that some metabolic activities or associated microbes in the tested paddy soil were stimulated by high concentration of AgNPs, which is named as the hormesis effect (Grün et al., 2018). To reveal the specific microbial mechanism in the hormesis effect of $50 \mathrm{mg} / \mathrm{kg}$ AgNPs on the tested paddy soil, the abundance of the denitrifying genes and bacterial gene were detected by realtime PCR. It was found that $50 \mathrm{mg} / \mathrm{kg}$ AgNPs decreased the abundance of nirS, nirK, cnorB, and nos $Z$ and bacterial gene copies in soil, but did not significantly changed the abundance of nar $G$ gene $(P<0.05)$, which is considered as the indicator of nitrate reductase (Yu et al., 2013). Further correlation analyses revealed that, though cumulative $\mathrm{N}_{2} \mathrm{O}$ emission was negatively correlated with bacterial abundance, it is positively correlated with the ratio of narG gene to the bacterial gene and with the ratio of the other four denitrifying genes to the bacterial gene. These results indicated that the narG gene could tolerate the toxicity of AgNPs in the case of all soil bacteria that were inhibited by $50 \mathrm{mg} / \mathrm{kg}$ AgNPs. In this situation, soil denitrifiers with narG gene could utilize the spare nitrogen and carbon 
resources that were occupied by the inhibited bacteria (Yang et al., 2013), and then more $\mathrm{NO}_{3}^{-}$was reduced to $\mathrm{NO}_{2}^{-}$. High $\mathrm{NO}_{2}^{-}$ concentrations subsequently promote denitrification processes and $\mathrm{N}_{2} \mathrm{O}$ production (Cai et al., 1997). A positive correlation between cumulative $\mathrm{N}_{2} \mathrm{O}$ emission and the ratio of nirS, nirK, cnor $B$, and nos $Z$ genes to the bacterial gene indicated that the denitrifying community could be more active than the other bacteria. In addition, it was reported that chemical process (e.g., chemodenitrification) is important for enhancing soil $\mathrm{N}_{2} \mathrm{O}$ production (Chen et al., 2018; Liu et al., 2019). In this study, the narG gene insensitive to AgNPs accumulated $\mathrm{NO}_{2}^{-}$in the tested soil, which could promote the chemodenitrification processes. As a result, the soil denitrification and $\mathrm{N}_{2} \mathrm{O}$ emission rates were significantly higher in $50 \mathrm{mg} / \mathrm{kg}$ AgNPs than that of CK.

\section{Key Microbial Phylotypes in Paddy Soil Exposed to AgNPs}

In paddy soils, microbes drive the denitrification processes in the anaerobic situation. The influence of high-concentration AgNPs on denitrification inevitably reflects in the change of some key phylotypes in soils (Yu et al., 2013; Grün et al., 2018). High-throughput sequencing showed a concentration effect of AgNPs on the microbial community composition, that is, the increase in the AgNP concentration tended to distribute in the microbial community. The difference of the distribution was found significant in the $50-\mathrm{mg} / \mathrm{kg}$-AgNP treatments. This result is consistent with the previous study on the influence of AgNPs on soil fungal community (Feng et al., 2013). Further analyses showed that $50 \mathrm{mg} / \mathrm{kg}$ AgNPs decreased most of the bacteria phyla, such as Acidobacteria, Actinobacteria, Elusimicrobia, and Cyanobacteria. This result corresponded to the toxicity of AgNPs on soil bacteria (Vandevoort et al., 2014). It has been demonstrated that the released AgNPs can damage the cell membrane and affect cellular viability by inducing the production of intracellular reactive oxygen species and free radicals (Hansch and Emmerling, 2010; Zhou, 2015), so the abundance of bacterial 16S rRNA gene was decreased in the 50-mg/kg-AgNP treatments. The denitrifying species in soils are mainly classified as Firmicutes and Proteobacteria (Throback et al., 2007). In this study, Clotridiales, Burkholderiales, and Anaerolineales, which are Firmicutes and $\beta$-proteobacteria, were significantly decreased by the $50-\mathrm{mg} / \mathrm{kg}-\mathrm{AgNP}$ treatment. This phenomenon suggested that these potentially functional denitrifiers can tolerate the toxicity of AgNPs. We also observed that the $50-\mathrm{mg} / \mathrm{kg}-\mathrm{AgNP}$ treatment increased Clotridiales and Burkholderiales. The thick cell walls of Clotridiales (Lee et al., 2013) and the good toxicity tolerance of Burkholderiales (Lee et al., 2013) could make the paddy soil possess higher denitrification than the CK treatments. Overall, Clotridiales, Burkholderiales, and Anaerolineales could be the key microbial species in the stimulation of $50 \mathrm{mg} / \mathrm{kg}$ AgNP on denitrification in the tested paddy soil.

\section{CONCLUSION}

The results of the present study demonstrate the influence of AgNPs on denitrification and microbial communities in a paddy soil. Here we show that soil denitrification and $\mathrm{N}_{2} \mathrm{O}$ emission were stimulated by $50 \mathrm{mg} / \mathrm{kg}$ AgNPs, while it is not susceptible to $0.1-10 \mathrm{mg} / \mathrm{kg}$ AgNPs. The tolerance of soil narG gene to $50 \mathrm{mg} / \mathrm{kg}$ AgNPs is the key factor which promotes denitrification in 50-mg/kg-AgNPtreated soils. The key bacterial phylotypes inducing high denitrification in 50-mg/kg-AgNP treatments could be Clotridiales, Burkholderiales, Anaerolineales, Clotridiales, and Burkholderiales in the tested paddy soil. These results provide valuable information for risk assessment of AgNPs on agricultural soils. However, our study was designed and performed in microcosm laboratory conditions. The performance of AgNPs on the natural ecosystem still needs further study in the future.

\section{DATA AVAILABILITY STATEMENT}

The original contributions presented in the study are included in the article/supplementary material, further inquiries can be directed to the corresponding author.

\section{AUTHOR CONTRIBUTIONS}

$\mathrm{XZ}$ and YY: conceptualization. XZ, DD, LZ, YW, and HL: methodology. XZ, DD, LZ, YW, and YY: formal analysis and investigation. XZ, LZ, and HL: writing-original draft preparation. DD, YW, and YY: writing-review and editing. YY: funding acquisition.

\section{FUNDING}

The authors acknowledge the financial support from Guangxi Key Science and Technology Innovation Base on Karst Dynamics (no. KDL\&Guangxi 202008) and the NUIST Students' Platform for Innovation and Entrepreneurship Training Program.

\section{REFERENCES}

Alvarez, L. H., and Cervantes, F. J. (2012). Assessing the impact of alumina nanoparticles in an anaerobic consortium: methanogenic and humus reducing activity. Appl. Microbiol. Biotechnol. 95, 1323-1331. doi: 10.1007/s00253-011-3759-4

Cai, Z., Xing, G., Yan, X., Xu, H., Tsuruta, H., Yagi, K., et al. (1997). Methane and nitrous oxide emissions from rice paddy fields as affected by nitrogen fertilisers and water management. Plant Soil 196, 7-14. doi: 10.1023/A:1004263405020

Cao, J., Feng, Y., He, S., and Lin, X. (2017). Silver nanoparticles deteriorate the mutual interaction between maize (Zea mays L.) and arbuscular mycorrhizal fungi: a soil microcosm study. Appl. Soil Ecol. 119, 307-316. doi: 10.1016/j.apsoil.2017. 04.011

Caporaso, J. G., Kuczynski, J., Stombaugh, J., Bittinger, K., Bushman, F. D., Costello, E. K., et al. (2010). QIIME allows analysis of highthroughput community sequencing data. Nat. Methods 7, 335-336. doi: $10.1038 /$ nmeth.f.303 
Chen, D., Liu, T., Li, X., Li, F., Luo, X., Wu, Y., et al. (2018). Biological and chemical processes of microbially mediated nitrate-reducing $\mathrm{Fe}(\mathrm{II})$ oxidation by Pseudogulbenkiania sp. strain 2002. Chem. Geol. 476, 59-69. doi: 10.1016/j.chemgeo.2017.11.004

Choi, O., and Hu, Z. Q. (2008). Size dependent and reactive oxygen species related nanosilver toxicity to nitrifying bacteria. Environ. Sci. Technol. 42, 4583-4588. doi: $10.1021 / \mathrm{es} 703238 \mathrm{~h}$

Delgado-Baquerizo, M., Maestre, F. T., Reich, P. B., Jeffries, T. C., Gaitan, J. J., Encinar, D., et al. (2016). Microbial diversity drives multifunctionality in terrestrial ecosystems. Nat. Commun. 7:10541. doi: 10.1038/ncomms10541

Edgar, R. C. (2013). UPARSE: highly accurate OTU sequences from microbial amplicon reads. Nat. Methods 10, 996-998. doi: 10.1038/nmeth.2604

Feng, Y., Cui, X., He, S., Dong, G., Chen, M., Wang, J., et al. (2013). The role of metal nanoparticles in influencing arbuscular mycorrhizal fungi effects on plant growth. Environ. Sci. Technol. 47, 9496-9504. doi: 10.1021/es402109n

Fine, P. V. A., and Kembel, S. W. (2011). Phylogenetic community structure and phylogenetic turnover across space and edaphic gradients in western Amazonian tree communities. Ecography 34, 552-565. doi: 10.1111/j.1600-0587.2010.06548.x

Gan, P. P., and Li, S. F. Y. (2012). Potential of plant as a biological factory to synthesize gold and silver nanoparticles and their applications. Rev. Environ. Sci. Bio-Technol. 11, 169-206. doi: 10.1007/s11157-012-9278-7

Goldberg, M. S. (2019). Improving cancer immunotherapy through nanotechnology. Nature Rev. Cancer 19, 587-602. doi: 10.1038/s41568-019-0186-9

Gottschalk, F., Sonderer, T., Scholz, R. W., and Nowack, B. (2009). Modeled environmental concentrations of engineered nanomaterials $\left(\mathrm{TiO}_{2}, \mathrm{ZnO}, \mathrm{Ag}\right.$, CNT, Fullerenes) for different regions. Environ. Sci. Technol. 43, 9216-9222. doi: $10.1021 /$ es 9015553

Grün, A.-L., Straskraba, S., Schulz, S., Schloter, M., and Emmerling, C. (2018). Long-term effects of environmentally relevant concentrations of silver nanoparticles on microbial biomass, enzyme activity, and functional genes involved in the nitrogen cycle of loamy soil. J. Environ. Sci. 69, 12-22. doi: 10.1016/j.jes.2018.04.013

Guo, Y., Cichocki, N., Schattenberg, F., Geffers, R., Harms, H., and Müller, S. (2019). AgNPs change microbial community structures of wastewater. Front. Microbiol. 9:3211. doi: 10.3389/fmicb.2018.03211

Hamad, A., Khashan, K. S., and Hadi, A. (2020). Silver nanoparticles and silver ions as potential antibacterial agents. J. Inorg. Organomet. Polymers Mater. 30, 4811-4828. doi: 10.1007/s10904-020-01744-x

Hansch, M., and Emmerling, C. (2010). Effects of silver nanoparticles on the microbiota and enzyme activity in soil. J. Plant Nutr. Soil Sci. 173, 554-558. doi: 10.1002/jpln.200900358

He, X., Deng, H., and Hwang, H.-M. (2019). The current application of nanotechnology in food and agriculture. J. Food Drug Anal. 27, 1-21. doi: 10.1016/j.jfda.2018.12.002

Huang, J., Cao, C., Liu, J., Yan, C., and Xiao, J. (2019a). The response of nitrogen removal and related bacteria within constructed wetlands after long-term treating wastewater containing environmental concentrations of silver nanoparticles. Sci. Total Environ. 667, 522-531. doi: 10.1016/j.scitotenv.2019.02.396

Huang, Y. N., Qian, T. T., Dang, F., Yin, Y. G., Li, M., and Zhou, D. M. (2019b). Significant contribution of metastable particulate organic matter to natural formation of silver nanoparticles in soils. Nat. commun. 10:3775. doi: 10.1038/s41467-019-11643-6

Kent, R. D., Oser, J. G., and Vikesland, P. J. (2014). Controlled evaluation of silver nanoparticle sulfidation in a full-scale wastewater treatment plant. Environ. Sci. Technol. 48, 8564-8572. doi: 10.1021/es404989t

Kumar, N., Shah, V., and Walker, V. K. (2011). Perturbation of an arctic soil microbial community by metal nanoparticles. J. Hazard. Mater. 190, 816-822. doi: 10.1016/j.jhazmat.2011.04.005

Lead, J. R., and Wilkinson, K. J. (2006). Aquatic colloids and nanoparticles: current knowledge and future trends. Environ. Chem. 3, 159-171. doi: 10.1071/EN06025

Lee, S. H., Kondaveeti, S., Min, B., and Park, H. D. (2013). Enrichment of Clostridia during the operation of an external-powered bioelectrochemical denitrification system. Process Biochem. 48, 306-311. doi: $10.1016 /$ j.procbio.2012.11.020
Ley, R. E., Bäckhed, F., Turnbaugh, P., Lozupone, C. A., Knight, R. D., and Gordon, J. I. (2005). Obesity alters gut microbial ecology. Proc. Natl. Acad. Sci. U.S.A. 102, 11070-11075. doi: 10.1073/pnas.0504978102

Liang, Z., Das, A., and Hu, Z. (2010). Bacterial response to a shock load of nanosilver in an activated sludge treatment system. Water Res. 44, 5432-5438. doi: 10.1016/j.watres.2010.06.060

Liu, S., Wang, C., Hou, J., Wang, P., Miao, L., Fan, X., et al. (2018). Effects of Ag and $\mathrm{Ag}_{2} \mathrm{~S}$ nanoparticles on denitrification in sediments. Water Res. 137, 28-36. doi: 10.1016/j.watres.2018.02.067

Liu, T., Chen, D., Luo, X., Li, X., and Li, F. (2019). Microbially mediated nitrate-reducing $\mathrm{Fe}(\mathrm{II})$ oxidation: quantification of chemodenitrification and biological reactions. Geochim. Cosmochim. Acta 256, 97-115. doi: 10.1016/j.gca.2018.06.040

Lowry, G. V., Avellan, A., and Gilbertson, L. M. (2019). Opportunities and challenges for nanotechnology in the agri-tech revolution. Nat. Nanotechnol. 14, 517-522. doi: 10.1038/s41565-019-0461-7

Maynard, A. D., Aitken, R. J., Butz, T., Colvin, V., Donaldson, K., Oberdorster G., et al. (2006). Safe handling of nanotechnology. Nature 444, 267-269. doi: $10.1038 / 444267 \mathrm{a}$

Nasrollahzadeh, M., Sajjadi, M., Iravani, S., and Varma, R. S. (2021). Green-synthesized nanocatalysts and nanomaterials for water treatment: current challenges and future perspectives. J. Hazard. Mater. 401:123401. doi: 10.1016/j.jhazmat.2020.123401

Olteanu, R. L., Nicolescu, C. M., and Bumbac, M. (2017). Influence of phytochemical reductive capacity on ultraviolet-visible spectroscopic behavior of silver nanoparticles. Anal. Lett. 50, 2786-2801. doi: 10.1080/00032719.2017.1298119

Parks, D. H., Tyson, G. W., Hugenholtz, P., and Beiko, R. G. (2014). STAMP: statistical analysis of taxonomic and functional profiles. Bioinformatics 30, 3123-3124. doi: 10.1093/bioinformatics/btu494

Pradas Del Real, A. E., Castillo-Michel, H., Kaegi, R., Sinnet, B., Magnin, V., Findling, N., et al. (2016). Fate of Ag-NPs in sewage sludge after application on agricultural soils. Environ. Sci. Technol. 50, 1759-1768. doi: 10.1021/acs.est.5b04550

Prosposito, P., Burratti, L., and Venditti, I. (2020). Silver nanoparticles as colorimetric sensors for water pollutants. Chemosensors 8:26. doi: 10.3390/chemosensors8020026

Radniecki, T. S., Stankus, D. P., Neigh, A., Nason, J. A., and Semprini, L. (2011). Influence of liberated silver from silver nanoparticles on nitrification inhibition of Nitrosomonas europaea. Chemosphere 85, 43-49. doi: 10.1016/j.chemosphere.2011.06.039

Salleh, A., Naomi, R., Utami, N. D., Mohammad, A. W., Mahmoudi, E., Mustafa, N., et al. (2020). The potential of silver nanoparticles for antiviral and antibacterial applications: A mechanism of action. Nanomaterials 10:1566. doi: 10.3390/nano10081566

Samarajeewa, A., Velicogna, J., Princz, J., Subasinghe, R., Scroggins, R., and Beaudette, L. (2017). Effect of silver nano-particles on soil microbial growth, activity and community diversity in a sandy loam soil. Environ. Pollut. 220, 504-513. doi: 10.1016/j.envpol.2016.09.094

Sun, T. Y., Gottschalk, F., Hungerbühler, K., and Nowack, B. (2014). Comprehensive probabilistic modelling of environmental emissions of engineered nanomaterials. Environ. Pollut. 185, 69-76. doi: 10.1016/j.envpol.2013.10.004

Throback, I. N., Johansson, M., Rosenquist, M., Pell, M., Hansson, M., and Hallin, S. (2007). Silver $\left(\mathrm{Ag}^{+}\right)$reduces denitrification and induces enrichment of novel nirK genotypes in soil. FEMS Microbiol. Lett. 270, 189-194. doi: 10.1111/j.1574-6968.2007.00632.x

Vandevoort, A. R., Skipper, H., and Arai, Y. (2014). Macroscopic assessment of nanosilver toxicity to soil denitrification kinetics. J. Environ. Qual. 43, 1424-1430. doi: 10.2134/jeq2013.12.0524

Wang, J., Shu, K., Zhang, L., and Si, Y. (2017). Effects of silver nanoparticles on soil microbial communities and bacterial nitrification in suburban vegetable soils. Pedosphere 27, 482-490. doi: 10.1016/S1002-0160(17) 60344-8

Whitley, A. R., Levard, C., Oostveen, E., Bertsch, P. M., Matocha, C. J., Von Der Kammer, F., et al. (2013). Behavior of Ag nanoparticles in soil: effects of particle surface coating, aging and sewage sludge amendment. Environ. Pollut. 182, 141-149. doi: 10.1016/j.envpol.2013.06.027 
Wilson, M. A., Tran, N. H., Milev, A. S., Kannangara, G., Volk, H., and Lu, G. (2008). Nanomaterials in soils. Geoderma 146, 291-302. doi: 10.1016/j.geoderma.2008.06.004

Yang, Y., Wang, J., Xiu, Z., and Alvarez, P. (2013). Impacts of silver nanoparticles on cellular and transcriptional activity of nitrogencycling bacteria. Environ. Toxicol. Chem. 32, 1488-1494. doi: 10.1002/ etc. 2230

Yaqoob, A. A., Umar, K., and Ibrahim, M. N. M. (2020). Silver nanoparticles: various methods of synthesis, size affecting factors and their potential applications-a review. Appl. Nanosci. 10, 1369-1378. doi: 10.1007/s13204-020-01318-w

Yu, Y., Wu, M., Petropoulos, E., Zhang, J., Nie, J., Liao, Y., et al. (2019). Responses of paddy soil bacterial community assembly to different long-term fertilizations in southeast China. Sci. Total Environ. 656, 625-633. doi: 10.1016/j.scitotenv.2018. 11.359

Yu, Y., Zhang, J., Chen, W., Zhong, W., Zhu, T., and Cai, Z. (2013). Effect of land use on the denitrification, abundance of denitrifiers, and total nitrogen gas production in the subtropical region of China. Biol. Fertil. Soils 50, 105-113. doi: 10.1007/s00374-013-0839-x

Zhang, H., Huang, M., Zhang, W., Gardea-Torresdey, J. L., White, J. C., Ji, R., et al. (2020). Silver nanoparticles alter soil microbial community compositions and metabolite profiles in unplanted and cucumberplanted soils. Environ. Sci. Technol. 54, 3334-3342. doi: 10.1021/acs.est. $9 \mathrm{~b} 07562$
Zheng, Y., Hou, L., Liu, M., Newell, S. E., Yin, G., Yu, C., et al. (2017). Effects of silver nanoparticles on nitrification and associated nitrous oxide production in aquatic environments. Science Adv. 3:e1603229. doi: 10.1126/sciadv.1603229

Zhou, D. M. (2015). Transport and transformation of nanoAg particle in soils and its environmental effects. Environ. Chem. 34, 605-613. doi: 10.7524/j.issn.0254-6108.2015.04.20150107

Conflict of Interest: The authors declare that the research was conducted in the absence of any commercial or financial relationships that could be construed as a potential conflict of interest.

Publisher's Note: All claims expressed in this article are solely those of the authors and do not necessarily represent those of their affiliated organizations, or those of the publisher, the editors and the reviewers. Any product that may be evaluated in this article, or claim that may be made by its manufacturer, is not guaranteed or endorsed by the publisher.

Copyright (C) 2021 Zhang, Dang, Zheng, Wu, Wu, Li and Yu. This is an open-access article distributed under the terms of the Creative Commons Attribution License (CC BY). The use, distribution or reproduction in other forums is permitted, provided the original author(s) and the copyright owner(s) are credited and that the original publication in this journal is cited, in accordance with accepted academic practice. No use, distribution or reproduction is permitted which does not comply with these terms. 